J. Perinat. Med. 17 (1989) 151

\section{Prematurity and maternal bronchial hyperresponsiveness}

\author{
Frank Riedel, Ulrike Achenbach, and Christian H. L. Rieger \\ Department of Pediatrics, Section of Immunology and Chest Disease, University \\ of Marburg, Marburg, West-Germany
}

\section{Introduction}

Neonatal lung disease after premature birth has been associated with long term pulmonary sequelae. Bronchial hyperreactivity, e.g., has been found in school children following long term ventilation during the neonatal period [11] and following bronchopulmonary dysplasia [1, 15]. A high incidence of airway hyperreactivity has also been described in children after premature birth without respiratory distress syndrome and in a high proportion of their mothers and siblings born at term [2]. As a relationship between familial airway hyperreactivity and premature birth was suggested by this work, it seemed important to further investigate mothers of preterm infants. It was the purpose of the present study to compare bronchial responsiveness to histamine among mothers of term infants and preterm infants with known and with unknown causes for prematurity.

\section{Material and methods}

Pulmonary function tests were performed in all mothers of neonates admitted to our neonatal ward during the years 1984-1987 provided informed consent was obtained and the following criteria were met:

Non-smoker for at least two years before pregnancy; no atopic disease (asthma, hay fever, eczema) including first degree relatives; no chronic lung disease; no acute airway infection during the preceeding 6 weeks; serum IgE $<100 \mathrm{IU} / \mathrm{ml}$ (Enzygnost ELISA, Behringwerke, Marburg, FRG); negative Type I skin reactions by prick test to 10 common inhalation allgergens (house dust mite, different pollen allergens, feathers, moulds).

\section{Curriculum vitae}

FRANK RIEDEL, M.D. studied medicine at Kiel University, Lübeck Medical School and Düsseldorf University, where he graduated in 1979. After a fellowship in respiratory medicine at the Royal Hospital for Sick Children in Edinburgh he received training in pediatrics in Lübeck, Hannover and Mar-

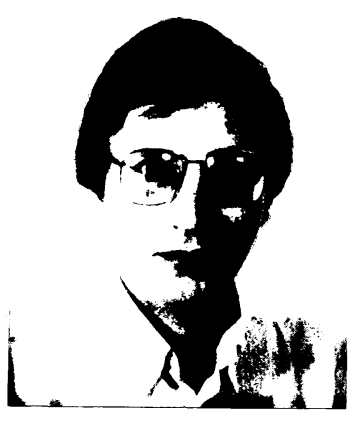
burg. Since 1986 he has been on the staff of the Division of Pediatric Pneumology and Immunology, Department of Pediatrics at Marburg University. His research fields are bronchial hyperreactivity and the association between air pollution and allergy.

The 60 mothers who participated in the study were separated into three groups:

Group I, mothers of term neonates ( $>37$ weeks of gestation) $n=20$;

Group II, mothers of preterm neonates $(<37$ weeks of gestation) with unknown cause of prematurity (idiopathic) $n=18$; Group III, mothers of preterm neonates in whom premature labour could be explained by some definite reason as defined below, $\mathrm{n}=22$.

Groups II and III were recruited from consecutive admissions in the years 1984-1987, whereas group I came from consecutive admission only in 1987. 
As explanations for preterm delivery were excepted: Multiple pregnancy, young age $(<16$ years) or advanced age ( $>35$ years), premature rupture of the fetal membranes without labour, abdominal trauma, intrauterine infection, abnormal placentation, structural uterine abnormalities, congenital malformations, EPH-gestosis, polyhydramnion, severe maternal illness during pregnancy and Rhesus-incompatibility.

The gestational age of the neonates was determined on the day of birth using the Farr-criteria [7].

Pulmonary function tests were performed at least four weeks after delivery and included vital capacity, functional residual capacity, residual volume, airway resistance and thoracic gas volume (bodyplethysmography) and forced expiratory flow measurements as described elsewhere [12].

Bronchial reactivity was measured by unspecific provocation testing with inhaled histamine using a modified version of the protocol described by Cockroft et al. [6]. Histamine dihydrochloride in buffered saline was nebulized in a $10 \mathrm{ltr}$ reservoir by pressure nebulizer (Pari, Starnberg, FRG, particle size $0.5-5 \mathrm{~mm}$, output $0.75 \mathrm{ml} / \mathrm{min}$ ) with increasing concentrations $(0.5-1-2-4-8 \mathrm{mg} /$ $\mathrm{ml})$. To fill the reservoir, $0.75 \mathrm{ml}$ of histamine solution and $120 \mathrm{sec}$ of nebulization were necessary. When the reservoir was filled, the nebulized aerosol was inhaled by tidal ventilation through a one way valve.

One and three minutes after the inhalation forced expiratory maneuvers were performed using a pneumotachygraph (Pneumoscreen, Maeger, FRG) and the best of three attempts, i. e. with the highest forced expiratory volume, was used for analysis. The histamine concentration producing a $20 \%$ fall in forced expiratory volumes in $1 \mathrm{sec}-$ ond $\left(\mathrm{PC}_{20, \mathrm{FEV}_{1}}\right)$ was determined from a semi-logarithmic dose-response curve.
All investigations were performed in the afternoon when bronchial reactivity is at its low part of circadian variation.

A $\mathrm{PC}_{20, \mathrm{FEV}_{1}}$-value $<8 \mathrm{mg} / \mathrm{ml}$ histamine was assumed to represent airway hyperreactivity according to population studies [4].

$\mathrm{PC}_{20, \mathrm{FEV}_{1}}$-figures were compared between the three groups using the Wilcoxon-Mann-Whitney-test; for comparison of the incidence of airway hyperreactivity (as defined above) we used FISCHER's exact test.

\section{Results}

Age and number of previous pregnancies did not differ among the three groups as shown in the table.

Basic pulmonary function tests were within normal limits in all investigated mothers, but bronchial reactivity differed significantly in group II $\left(\mathrm{PC}_{20, \mathrm{FEV}_{1}}=4.25(0.9->8.0) \mathrm{mg} / \mathrm{ml}\right.$ histamine, median and range) from both other groups (group I, $\quad \mathrm{PC}_{20, \mathrm{FEV}_{1}}=>8.0 \quad(0.55->8.0) \mathrm{mg} / \mathrm{ml}$, $\mathrm{p}<0.002$; group III, $\mathrm{PC}_{20, \mathrm{FEV}_{1}}=>8.0(1.5-$ $<8.0) \mathrm{mg} / \mathrm{ml}, \mathrm{p}<0.05$; figure)

Accordingly, the incidence of bronchial hyperreactivity was significantly higher in group II (12 of 18) than in group I ( 3 of $20, p<0.02)$, the latter corresponding to the normal incidence of airway hyperreactivity in a healthy population [4]. Between group II and III the incidence of bronchial hyperreactivity was not statistically different $(\mathrm{p}=0.55)$, although more hyperreactive mothers were found in group II (12 of 18 vs. 8 of 22).

One of the three mothers in group I with increased bronchial reactivity $\left(\mathrm{PC}_{20, \mathrm{FEV}_{1}}\right.$ of $3.7 \mathrm{mg} / \mathrm{ml}$ histamine) reported having had some mild uterine contractions at $26^{\text {th }}$ week of gestation which ceased spontaneously.

Table I. Age and numbers of previous pregnancies among the three groups (not different).

\begin{tabular}{lllc}
\hline & Group I & Group II & Group III \\
\hline $\mathrm{n}$ & 20 & 18 & 22 \\
$\begin{array}{l}\text { Age (y) } \\
\text { (median, range) }\end{array}$ & $29(22-36)$ & $28(20-35)$ & $30.5(16-41)$ \\
$\begin{array}{l}\text { No. of previous pregnancies } \\
\text { (median, range) }\end{array}$ & $0 \quad(0-9)$ & $0 \quad(0-1)$ & 0 \\
\hline
\end{tabular}




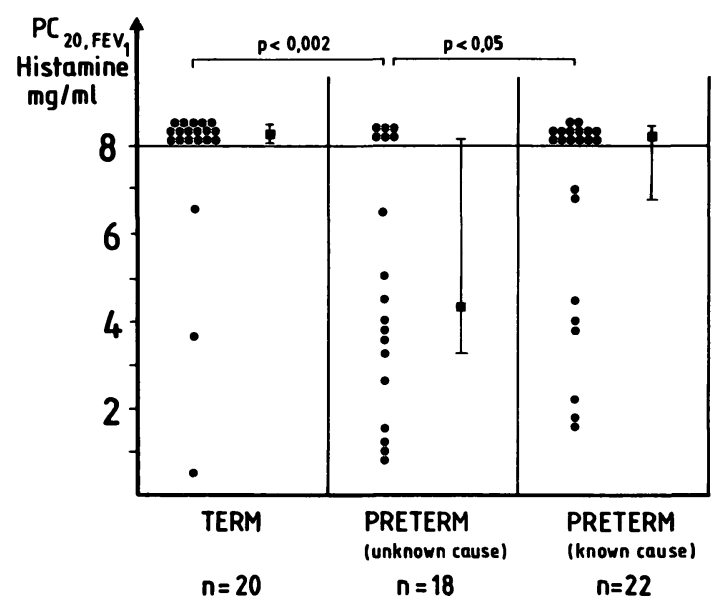

Figure 1. Unspecific bronchial reactivity on histamine provocation $\left(\mathrm{PC}_{\left.20, \mathrm{FEV}_{1}\right)}\right)$ in mothers of term infants and of newborns with explained and idiopathic prematurity, expressed as single values (dot) and median (square) with $95 \%$ confidence limit.

\section{Discussion}

Mothers with preterm delivery of unknown cause (idiopathic prematurity) have a significantly increased airway reactivity compared to both mothers of term neonates and mothers of preterm neonates with a defined cause of preterm delivery.

The high incidence of bronchial hyperreactivity in mothers with preterm delivery of unknown origin cannot be explained by one of the factors which are known to be associated with increased bronchial reactivity (atopy, smoking, chronic lung disease, recent airway infection, etc.) as these factors were part of the exclusion criteria for the study.

The effect of pregnancy on bronchial reactivity is not known, but as bronchial reactivity was measured at least four weeks after delivery an influence of pregnancy is unlikely.

Although due to strict exclusion criteria the numbers in each group are small, bronchial reactivity is obviously highest in the mothers with unexplained prematurity. The WILCOXON test, which we used for statistical analysis in addition to FISCHER's exact test, has its limitation due to zensored values above $\mathrm{PC}_{20, \mathrm{FEV}_{1}}$ of $8 \mathrm{mg} / \mathrm{ml}$ histamine. When using this method for measuring bronchial reactivity, it does not seem justified to further increase histamine concentrations in healthy women above $8 \mathrm{mg} / \mathrm{ml}$ until significant bronchial obstruction occurs, as non specific side effects occur (e.g. cough, flush, throat irritation and headache) under these circumstances before bronchial obstruction is observed.

One of the hypotheses about the pathogenesis of bronchial hyperreactivity implies an imbalance within the autonomic nervous system [3] which has an important role in uterine innervation and function [13]. Beta-2-agonists, the drugs of first choice in bronchial asthma, are the main agents for inhibition of premature labour [10]. Furthermore, the potent bronchoconstrictor Prostaglan$\operatorname{din} \mathrm{F} 2 \alpha[14]$, is one of the main mediators responsible for cervical softening and uterine contractions in premature delivery [8].

Thus, a similar basic mechanism influencing uterine and airway smooth muscle activity may be operating in some women leading to airway hyperresponsiveness and premature labor.

As bronchial hyperreactivity is partly inherited [9], airway hyperresponsiveness in the preterm neonates of these mothers may not entirely be explained by acquired lung damage due to prematurity, oxygen treatment or neonatal ventilation, but may also be related to a genetically determined bronchial hyperreactivity.

This may also explain why premature infants, even in the absence of BPD have a higher morbidity following RSV- and other respiratory tract viral infections [5]. They represent a risk group for later bronchial disease, not due to early bronchial damage but due to inherited bronchial hyperreagibility, and should be followed up carefully in this regard.

\footnotetext{
Abstract

Bronchial reactivity was compared among mothers of neonates with unexplained premature delivery and mothers of preterm neonates with known etiology of prematurity as well as mothers who deliverd their children at term. Bronchial reactivity was measured by unspecific bronchial provocation testing with histamine.
}

A significantly higher incidence of bronchial hyperreactivity was found among mothers with unexplained prematurity as compared to the control groups.

An imbalance in the autonomic nerve system leading to prematurity as well as bronchial hyperresponsiveness is suggested.

Keywords: Bronchial provocation test, maternal bronchial hyperresponsiveness, premature labour. 


\section{Zusammenfassung}

\section{Frühgeburtlichkeit und bronchiale Hypersensibilität bei der Mutter}

Bei Frühgeborenen beobachtet man in der Kindheit eine höhere Prävalenz von bronchialer Hyperaktivität. Diskutiert wird daher ein Zusammenhang zwischen Prämaturität und einer familiären Belastung hinsichtlich bronchialer Hyperreaktionen. Wir haben die bronchiale Reaktivität von drei Gruppen miteinander verglichen: Mütter mit Reifgeborenen (Gruppe $I, n=20$ ), Mütter mit Frühgeburten unklarer Ursache (Gruppe II, $\mathrm{n}=18$ ) und Mütter mit Frühgeburten bekannter Ätiologie (Gruppe III, $\mathrm{n}=22$ ).

Mütter mit chronischen Lungenerkrankungen, atopischer Disposition (Anamnese, $\mathrm{IgE}>100 \mathrm{U} / \mathrm{ml}$ ), gerade abgelaufenen Infekten des Respirationstraktes sowie Raucherinnen wurden ausgeschlossen. Die bronchiale Reaktivität wurde über einen unspezifischen Provokationstest mit Histamin gemessen. Aus der Dosis-Antwort-Kurve wurde die Histaminkonzentration berechnet, die einen $20 \%$ igen Abfall der 1-Sekunden-Kapazität zur Folge hatte $\left(\mathrm{PC}_{20, \mathrm{FEV}_{1}}\right)$.

Die Inzidenz von bronchialer Hyperreaktivität $\left(\mathrm{PC}_{20, \mathrm{FEv}_{1}}<8 \mathrm{mg} / \mathrm{ml}\right)$ war in Gruppe II (12 von 18) höher als in Gruppe I ( 3 von 20, $p<0.02)$ und in Gruppe III (8 von $22, p=0.055)$. Darüberhinaus war der $\mathrm{PC}_{20, \mathrm{FEV}_{1}}$-Wert in Gruppe II signifikant niedriger (Median $=4,25 \mathrm{mg} / \mathrm{ml}$ ) als in den beiden anderen Gruppen (Mediane $>8 \mathrm{mg} / \mathrm{ml}, \mathrm{p}<0,05$, Fig. 1). Zwischen
Gruppe I und Gruppe III gab es keine signifikanten Unterschiede.

Die hohe Inzidenz von bronchialen Hypersensibilitäten bei Müttern mit Frühgeburten unklarer Genese könnte auf ein Ungleichgewicht innerhalb des autonomen Nervensystems hinweisen, das Einfluß auf die Uterusmuskulatur und die glatte Muskulatur der Luftwege hat und somit bronchiale Hyperreaktivität bedingt wie auch vorzeitige Wehen auslöst.

Neonatale Lungenaffektionen nach Frühgeburt wurden mit Langzeitveränderungen an der Lunge in Zusammenhang gebracht. Bronchiale Hyperreaktivität ganz allgemein wurden bei Schulkindern nach Langzeitbeatmung in der Neonatalphase [11] und nach bronchopulmonalen Dysplasien [1, 15] gefunden. Auch bei Frühgeborenen ohne RDS wurden später gehäuft Überempfindlichkeiten der Luftwege beschrieben. Dasselbe gilt für deren Mütter und reifgeborene Geschwister [2]. Da auch die vorliegende Arbeit auf einen Zusammenhang zwischen familiärer Häufung von bronchialer Hyperreaktivität und Frühgeburtlichkeit hinweist, sollten die Mütter von Frühgeborenen genauer untersucht werden. Ziel dieser Studie war der Vergleich der bronchialen Ansprechbarkeit auf Histamin zwischen Müttern von Reifgeborenen und Frühgeborenen, zum einen mit bekannter, zum anderen mit unbekannter Ursache für die Frühgeburtlichkeit.

Schlüsselwörter: Bronchiale Hypersensibilität bei der Mutter, bronchialer Provokationstest, Frühgeburt.

\section{Résumé}

\section{Prématurité et hyperréactivité bronchique maternelle}

Il a été montré que les nouveaux-nés prématurés présentent une prévalence élevée d'hyperréactivité bronchique ultérieurement dans l'enfance, et il a été suggéré une association entre prématurité et hyperréactivité bronchique familiale.

Nous avons comparé la réactivité bronchique des mères ayant accouché prématurément sans cause (groupe II, $\mathrm{n}=18$ ) avec celle de mères ayant accouché prématurément avec une cause connue de prématurité (groupe III, $\mathrm{n}=22$ ) et celle de mères ayant accouché à terme (groupe $\mathrm{I}, \mathrm{n}=20$ ).

Nous avons exclu les mères ayant une pathologie pulmonaire chronique, une disposition atopique (antécédents, $\mathrm{IgE}>100 \mathrm{U} / \mathrm{ml}$, test cutané positif), un tabagisme et des infections de l'arbre respiratoire récentes. La réactivité bronchique a été mesurée par des tests de provocation bronchique non spécifiques à l'histamine. On a calculé à l'aide d'une courbe dose-réponse $\left(\mathrm{PC}_{20, \mathrm{FEV}_{1}}\right)$ la concentration qui entraine une baisse de $20 \%$ du volume expiratoire forcé en une seconde.

L'incidence de l'hyperréactivité bronchique $\left(\mathrm{PC}_{20, \mathrm{FEV}_{1}}\right.$ $<8 \mathrm{mg} / \mathrm{ml})$ est plus élevée dans le groupe II $(12 / 18)$ que dans les deux autres groupes (vs groupe $I=3 / 20=p$
$<0,02$; vs groupes III $=8 / 22=p=0,055$ ). En outre, la $\mathrm{PC}_{20, \mathrm{FEV}_{1}}$ dans ce groupe II est significativement plus basse $(4,25 \mathrm{mg} / \mathrm{ml}$ en moyenne) que dans les deux autres groupes (moyennes $8 \mathrm{mg} / \mathrm{ml}$, p 0,05; voir la figure). Il n'y a pas de différence significative dans la réactivité bronchique entre les groupes I et III.

L'incidence élevée d'hyperréactivité bronchique chez les mères ayant eu un accouchement prématuré inexpliqué indique un déséquilibre du système nerveux autonome influençant l'activité musculaire lisse de l'utérus et de l'arbre respiratoire et conduisant à une hyperréactivité bronchique ainsi qu'au travail prématuré.

Les affections pulmonaires néonatales après accouchement prématuré s'accompagnent de séquelles pulmonaires à long terme. Par exemple, on a trouvé une hyperréactivité bronchique chez les enfants scolarisés succédant à une ventilation à long terme au cours de la période néonatale [11] et compliquant une dysplasie broncho-pulmonaire $[1,15]$. On a également décrit une incidence élevée d'hyperréactivité de l'arbre respiratoire chez des enfants nés prématurément sans syndrome de détresse respiratoire ainsi que chez leus mères dans une proportion élevée [2]. Comme une relation entre une hyperréactivité familiale de l'arbre respiratoire et l'ac- 
couchement prématuré est suggérée par ce travail, il semble important d'explorer ultérieurement les mères des enfants prématurés. C'est l'objectif de cette étude de comparer la réponse bronchique à l'histamine des mères d'enfants à terme et d'enfants prématurés ayant ou n'ayant pas de cause connue à la prématurité.

Mots-clés: Accouchement prématuré, hyperréactivité bronchique maternelle, test de provocation bronchique.

\section{References}

[1] Bader D, AD Ramos, CD Lew, ACG PlatzKer, MW Stabile, IG KeENS: Childhood sequelae of infant lung disease: Exercise and pulmonary function abnormalities after bronchopulmonary dysplasia. J pediatr 110 (1987) 693

[2] Bertrand JM, SP Riley, J Popkin, Al Coates: The long-term pulmonary sequelae of prematurity: The role of familial airway hyperreactivity and the respiratory distress syndrome. N Engl J Med 312 (1985) 742

[3] Boushey HA, MJ Holtzman, JR Sheller, JA NADEL: Bronchial Hyperreactivity. Am Rev Respir Dis 121 (1980) 389

[4] Burney PGJ, JR Britton, S Chinn, AE TattersFIELD, AO Papacosta, MC Kelson, F ANDERSON, DR CORFIELD: Descriptive epidemiology of bronchial reactivity in an adult population: Results from a community study. Thorax 42 (1987) 38

[5] Chruch NR, NG anas, CB Hall, JG Brooks: Respiratory syncytial virus-related apnea in infants. Demographics and outcome. Am J Dis Child 138 (1984) 247

[6] CockCroft DW, DN Killian, JJA Mellon, FE HARGREAVE: Bronchial reactivity to inhaled histamine: a method and clinical survey. Clin Allergy 7 (1977) 235

[7] Farr V, R Mitchell, G Neligan et al: The definition of some external characteristics used in the assessment of gestational age of the newborn infant. Dev Med Child Neurol 8 (1966) 507

[8] Gravetr MG: Causes of Preterm Delivery. Semin Perinatol 8 (1984) 246
[9] Hargreave FE, J Dolovich, PM O'Barne, EH RAMSDALE, EE DANIEL: The origin of airway hyperresponsiveness. J Allergy Clin Immunol 78 (1986) 825

[10] Ingemarsson I: Use of $\beta$-Receptor Agonists in Obstetrics. Acta Obstet Gynecol Scand 108 (1982) 29

[11] RIEDEL F: Long Term Effects of Artificial Ventilation in Neonates. Acta Paediatr Scand 76 (1987) 24

[12] RIEDEL F, H vON DER HARDT: Variable Response to Inhaled Salbutamol of Different Lung Function Parameteres in Healthy Children. Lung 164 (1986) 333

[13] Sternouist M, C Owman: Cholinergic and adrenergic neurol control of smooth muscle function in the non-pregnant rat uterine cervix. Acta Physiol Scand 124 (1985) 429

[14] Smith AP, MF CuthBert, LS Dunlop: Effects of innaled prostaglandin E1, E2, and F2 $\alpha$ on the airway resistance of healthy and asthmatic man. Clin Sci Mol Med 48 (1975) 421

[15] Smyth JA, E Tabachnik, WJ Duncan, BJ Reilly, H LEVISON: Pulmonary function and bronchial hyperreactivity in long-term survivors of bronchopulmonary dysplasia. Pediatrics 68 (1981) 336

Received August 8, 1988. Revised January 30, 1989. Accepted February 4, 1989.

Frank Riedel, M.D.

Zentrum für Kinderheilkunde

der Philipps-Universität

Deutschhausstraße 12

D-3550 Marburg, West Germany 